DOI: $10.2478 / \mathrm{v} 10025-011-0001-9$

\title{
Principles of hydromorphological surveys of Polish rivers
}

\author{
Piotr ILNICKI I) Krzysztof GÓRECKI ${ }^{1)}$, Mirostaw GRZYBOWSKI ${ }^{2}$, \\ Alicja KRZEMIN'SKA ${ }^{3)}$, Piotr LEWANDOWSKI ${ }^{1)}$, Mariusz SOJKA ${ }^{4)}$
}

1) Poznań University of Life Sciences, Department of Environmental Protection, 60-594 Poznań, ul. Dąbrowskiego 159, Poland; ilnickip@up.poznan.pl

2) University of Warmia and Mazury in Olsztyn, Department of Applied Ecology, 10-857 Olsztyn, ul. Oczapowskiego 5, Poland; grzybomi@uwm.edu.pl

3) Wrocław University of Environmental and Life Sciences, Department of Landscape Architecture, 50-363 Wrocław, pl. Grunwaldzki 24a, Poland; a-krzem@tlen.pl

4) Poznań University of Life Sciences, Department of Land Reclamation, Environmental Management and Geodesy, 60-649 Poznań, ul. Piątkowska 94E, Poland; masojka@up.poznan.pl

\begin{abstract}
This paper presents the key principles of the new Polish methodology for hydromorphological river surveys which is consistent with the provisions of the Water Framework Directive. This method proposes to investigate only the main watercourse of the water body. The assessment is based on cartographic maps, satellite images and the existing databases. Field surveys are limited to selected stretches of the water body. The classification of the river's ecological status and ecological potential is based on a hierarchical system comprising four elements: hydrological regime, river continuity, channel morphology and floodplain. They are evaluated in view of features characterized by selected attributes. The method is the same for natural and heavily modified water bodies, while a simplified methodology is used to investigate artificial water bodies. It does not account for differences in abiotic type, landscape or size of the catchment area. The results are presented in abridged and field protocols. The attributes are evaluated on a five-point grading scale or through a descriptive approach which supports the calculation of ecological quality ratios for quality elements, hierarchical system elements and the water body. The usefulness of the proposed method has been tested on 11 pilot water bodies. The presented approach enables to perform hydromorphological surveys of Polish rivers by 2015 , as required under the Water Framework Directive.
\end{abstract}

Key words: hydromorphological method, monitoring, river survey, Water Framework Directive

\section{INTRODUCTION}

The Water Framework Directive (WFD) 2000/60/EC has placed the Member States under an obligation to evaluate the ecological status and the ecological potential of their rivers. Such assessments investigate the biological, hydromorphological, physical and chemical elements of watercourses. For many years, EU 
members have been developing various methods for evaluating the above parameters, and a common methodological approach is not required. As part of the Common Implementation Strategy (CIS) of the WFD (2003) for 2003-2009, twenty two guidance documents have been developed to assist Member States in accomplishing this difficult task. Whereas various methods have been proposed for surveying selected biological elements, Poland has not developed a uniform approach to monitoring river hydromorphology. There are no methods for the collective presentation of evaluation results for all elements of the water body. The aim of ecomorphological surveys initiated in the 1980s was to change the perception of watercourses from that of drainage reservoirs to habitats of valuable flora and fauna species. As of 1995, ecomorphological river surveys in Poland involved an evaluation of selected features and attributes based on a point scale (ILNICKI and LEWANDOWSKI, 1995). Beginning in 2004, the British River Habitat Survey method was also deployed (SzOsZKIEWICZ et al., 2004). The key principles of the new Polish methodology for hydromorphological river surveys (MHR), approved by the Chief Inspectorate for Environmental Protection in Warsaw in December 2009 (ILNICKI et al., 2009), are presented below.

\section{LEGAL AND FORMAL GROUNDS FOR THE PROPOSED METHODOLOGY}

The scope of hydromorphological survey methods is dictated by the Water Framework Directive 2000/60/EC, the guidelines of standard EN14614 developed by the European Committee for Standardization CEN-TC 230 in 2004, and European guidance standard prEN 15843 approved in 2009. The first standard identifies 10 quality elements for assessing a river's hydromorphological condition, while the second determines the methodology for their evaluation.

The proposed method has to be consistent with the provisions of Directive No. 1882/2003 of 29 September 2003 standardizing and rationalizing environmental reports (EC Reporting Directive) and dedicated software developed for the European Commission in 2009 by Atkins Ltd. The discussed method has to be compatible with the Water Information System for Europe (WISE) developed since 2007 and the Shared Environmental Information System (SEIS) as part of which the European Environmental Agency has to be provided with a data dictionary for rivers, termed WISE-SoE: Rivers (formerly Eionet-Water). In 2009, WFD codes and indicators of hydromorphological quality elements were defined for reporting purposes (Tab. 1 and 2). The proposed method also falls subject to the provisions of Directive 2007/2/EC establishing an Infrastructure for Spatial Information in the European Community (INSPIRE) and metadata services. The transposition of the above provisions into the Polish law has not yet been completed.

An analysis of the numerous methods for hydromorphological river surveys developed in Europe in the past 25 years has contributed significantly to the pro- 
Table 1. Parameters for the point rating of the hydromorphological status of natural water bodies and heavily modified water bodies in the MHR method - Elements 1 and 2 Codes of hydromorphological elements - Value QE2 Hydromorphstatusorpotential

\begin{tabular}{c|c}
\hline Feature and code & Evaluated attribute (scale of 1-5 points) \\
\hline
\end{tabular}

\section{Element 1: hydrological regime - QE2-1}

W-1 water flow QE2-1-1

changes in SSQ for (1981-2000):(1961-1980)

flood risk: $S S Q: S W Q$ for 1981-2000

drought risk: $S N Q: S S Q$ for 1981-2000

W-2 flow characteristic

disturbances caused by: reservoirs, water uptake, water transfer

QE2-1-1-1

$\mathrm{W}-3$ connection to groundwater bodies QE2-1-2

W-4 water uptake, transfer and retention QE2-1-1-4

$\%$ share of ground runoff (lowland water bodies only)

broken connections between surface and underground water bodies surface water uptake: $>1 \mathrm{~m}^{3} \cdot \mathrm{s}^{-1}$ and for more than 10 ha of ponds underground water uptake: $>5000 \mathrm{~m}^{3} \cdot \mathrm{d}^{-1}$ wastewater discharge: $>3000 \mathrm{~m}^{3} \cdot \mathrm{d}^{-1}$ water transfer discharge of cooling water or water with a chloride load $>1 \mathrm{~kg} \cdot \mathrm{s}^{-1}$ hydroelectric power station: output $>5 \mathrm{MW}$

weir afflux (length of water body)

flood polders: $>20$ ha

flows out or through a lake ( $>50 \mathrm{ha})$

Element 2: river continuity - QE2-2

W-5 damming structures length of water body (\%) with limited possibility of fish migration

Note: The referenced features codes are based on "A user guide to the WFD Reporting Schemas (2009)", and they have been adapted for the needs of the MHR method.

Explanations: $S N Q$ - minimal annual discharge, $S S Q$ - mean annual discharge, $S W Q$ - high annual discharge.

posed methodology. Most of the analyzed approaches do not fully conform to the above legislative provisions, and they tend to disregard survey elements relating to the hydrological regime and river continuity. The analysis focused on the choice of the evaluated elements and features. The studies have an interdisciplinary character, and they should account for recent findings in natural sciences, water management and land reclamation.

A report on Poland's water bodies (Raport..., 2005), the Atlas of Hydrographic Area Boundaries in Poland (Atlas..., 2005) and the Regulation of the Minister of the Environment on the classification and monitoring of ecological status, implemented in 2008-2009, have also contributed to the proposed methodology. The new method has to account for the classification of water bodies into various categories (natural, heavily modified, artificial), abiotic river types (a total of 26 have been identified), the size and characteristics of catchment areas (lowlands, highlands, mountains, physiographic mesoregions). Hydromorphological surveys 
Table 2. Parameters for the point rating of the hydromorphological status of natural water bodies and heavily modified water bodies in the MHR method - Elements 3 and 4

\begin{tabular}{|c|c|}
\hline Feature and code & Attribute \\
\hline \multicolumn{2}{|c|}{ Quality element 3: river channel morphology - QE2-3 } \\
\hline \multirow[t]{3}{*}{ W-6 planform QE2-2-3 } & range of watercourse regulation (\% length) \\
\hline & sinuosity index \\
\hline & number of channels \\
\hline W-7 longitudinal profile QE2-3-4 & variability of longitudinal slope \\
\hline \multirow[t]{6}{*}{ W-8 cross profile QE2-3-1 } & variability of length, depth, bank inclination \\
\hline & profile regularity \\
\hline & bank slope \\
\hline & presence of natural channel forms \\
\hline & aggregate/stone mining in the river channel \\
\hline & length $(\%)$ of embankments \\
\hline W-9 river bed substrate QE2-3-2 & cannot be assessed \\
\hline $\begin{array}{l}\text { W-10 revetment of the channel } \\
\text { QE2-3-2-1 }\end{array}$ & $\begin{array}{l}\text { share }(\%) \text { of bed protection in the length of the water body } \\
\text { sediment discharge }\end{array}$ \\
\hline \multirow{7}{*}{$\begin{array}{l}\text { W-11 river channel vegetation } \\
\text { QE2-3-2-3 }\end{array}$} & presence of coarse wood debris \\
\hline & presence of numerous exposed roots on the bank \\
\hline & aquatic vegetation cover on the water table $(\%)$ \\
\hline & rush cover on the bank \\
\hline & annual bank cutting and plant removal \\
\hline & river shading \\
\hline & presence of trees and shrubs on the bank \\
\hline \multirow{3}{*}{$\begin{array}{l}\text { W-12 structure of the riparian zone } \\
\text { (width of } 10 \mathrm{~m} \text { from the upper edge of } \\
\text { escarpment) QE2-3-3 }\end{array}$} & share $(\%)$ of areas not used for farming \\
\hline & share of developed areas \\
\hline & zone continuity \\
\hline \multicolumn{2}{|c|}{ Element 4: floodplain QE2-4 } \\
\hline \multicolumn{2}{|c|}{$\begin{array}{l}\text { W-13 valley characteristics cannot be assessed } \\
\text { QE2-4-3-1 }\end{array}$} \\
\hline \multirow[t]{3}{*}{ W-14 land use QE2-4-3-2 } & share of semi-natural and natural areas \\
\hline & share of grassland \\
\hline & share of developed areas \\
\hline \multirow[t]{2}{*}{ W-15 flood embankments QE2-4-3-3 } & share of periodically flooded areas \\
\hline & width of the inter-embankment zone \\
\hline $\begin{array}{l}\text { W-16 nature conservation areas } \\
\text { QE2-4-3-4 }\end{array}$ & share of protected valley areas \\
\hline
\end{tabular}

should also rely on data supplied by surveys investigating other parameters of a river's ecological status as well as the location of control points for monitoring biological, physical and chemical elements.

A total of 4508 water bodies identified in Poland have a combined length of around $110,000 \mathrm{~km}$. Due to high monitoring costs, a simple evaluation method is 
required. Hydromorphological river surveys cover the entire water body. This approach constitutes the main difference between the discussed method and methods that evaluate ecological status parameters based on a system of control points.

An effective hydromorphological survey method has to account for the availability, cost, update status and range of cartographic maps, orthophotomaps, satellite geographic information systems (geographic information portals), hydrological databases and databases managed by watercourse administrators.

The discussed method should support the calculation of the analyzed river's ecological quality ratio $(E Q R)$ based on selected four elements, features and attributes evaluated on a point scale or through a descriptive approach. A set of reference conditions (river's natural condition) should be established for evaluating the river's present ecological status. Based on $E Q R$ values, a river's ecological status or ecological potential is classified into five or four classes. Owing to such extensive requirements, the development of a method for evaluating the hydromorphological attributes of Polish rivers is a complex process. A simple method characterized by low cost and low labor intensity is, therefore, required to address the above problem.

\section{METHODOLOGY FOR HYDROMORPHOLOGICAL RIVER SURVEYS (MHR)}

In view of varied hydrological features, mainly the diverse morphology of river channels and valleys, surveys have to cover the entire length of a water body, rather than subjectively selected sections with a length of 100-1000 m or monitoring points for assessing the biological, physical and chemical attributes of watercourses. The latter approach would produce numerous errors and it would not support a correct evaluation of ecological status. For this reason, the analogue principle may not be adopted in the first, six-year surveillance cycle. In addition to the main watercourse, water bodies often comprise tributaries with a completely different hydrological regime and morphological parameters; therefore, surveys have to be limited to their main watercourse. This approach narrows down the scope of the investigation from $110,000 \mathrm{~km}$ to around $75,000 \mathrm{~km}$.

The proposed method does not account for water categories, landscapes, catchment areas and abiotic types as this diversity of features would require dozens of survey methods. In view of inaccurate criteria for differentiating natural water bodies from heavily modified waters, a single method has been developed for them and a separate method has been proposed for artificial watercourses. A similar approach has been adopted by the majority of European countries, some of which introduced separate methods for rivers with very large catchment areas $(>10000$ $\mathrm{km}^{2}$ ).

Surveillance elements and the applicable features and attributes have been carefully selected to ensure that the proposed method delivers reliable results at 
a relatively low cost. The features and attributes presented in Tables 1 and 2 have been chosen in view of the existing survey methods in Central Europe and the need to evaluate highly diverse parameters. Quality element codes for reporting to the European Commission are also indicated. Each of the four quality elements are assessed in view of several features and the features are evaluated based on selected attributes. A series of features (W-9, W-13), mostly attributes, are presented in descriptive form only (Tab. 3). The above applies to catchment area size, flow volume and valley characteristics. Flow volume is determined by the size of the catchment area, and it does not characterize a water body's ecological status or ecological potential. The evaluation of hydrological regime poses greatest difficulty. Landscapes and abiotic types have been taken into account to assess only selected features. Abiotic types have been combined into six groups to avoid errors

Table 3. Attributes evaluated by the MHR method in a descriptive approach only

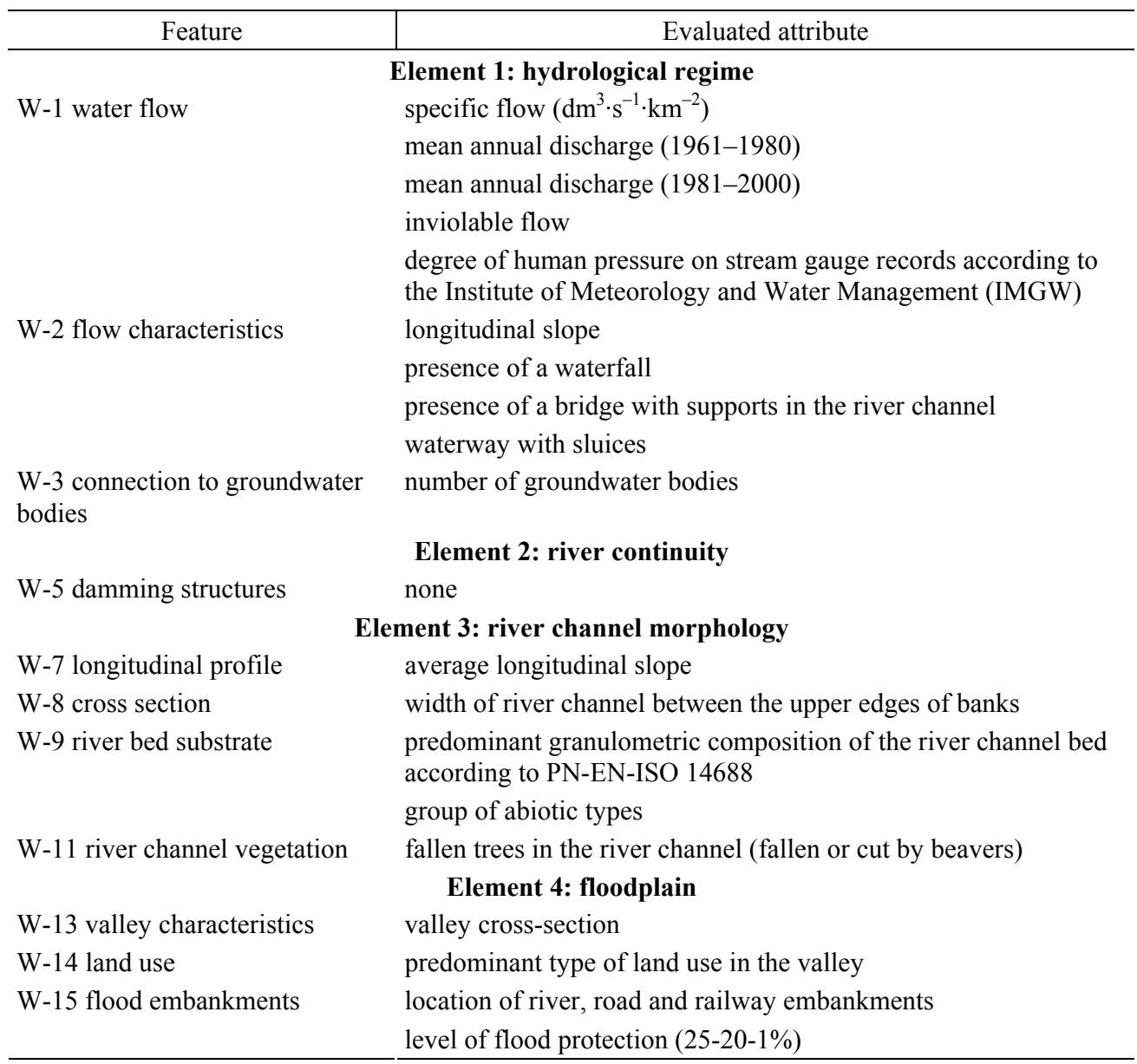


in their identification (ILNICKI et al., 2010). The river substratum has been described based on standard PN-EN ISO 14688-2:2006.

Topographic maps in the 1:50 000 scale (reference maps) and 1:10 000 (detailed maps) were regarded as most useful for the study. Analogue and digital orthophotomaps (satellite geographic information system) with $0.5 \mathrm{~m}$ resolution, available from Regional Centers for Geodetic and Cartographic Documents, (www.wodgik.pl), were also used. Geoportal (www.geoportal.gov.pl), Google Maps http://maps.google.com), Geoserwer.pl (www.geoserwer.pl) and Zumi.pl (www.zumi.pl) websites proved to be valuable sources of data. Other reference materials involved theme maps (raster maps of hydrographic area boundaries in Poland, soil and agricultural map in the 1:100 000 scale, geological maps, wetland maps, updated maps of nature protection areas and other), hydrological and hydrographic atlases and data from reports developed for the Ministry of Environment. Hydrological data are available solely in the database of the Institute of Meteorology and Water Management (IMGW), and information on the scope of regulation, the condition of watercourses and hydroengineering structures can be obtained from Regional Water Management Authorities (RZGW) and Land Reclamation and Water Structure (ZMiUW) Authorities. The data acquired during hydromorphological surveys are to be compiled in a new database.

The main documents applied in the MHR method are office protocols. Identical protocols are developed for natural and heavily modified water bodies, while artificial water bodies are described by simplified protocols. Field protocols are identical for all water bodies. An abridged protocol comprises nine pages for most water bodies. The first page contains basic information on the investigated water body, the number of field protocols and digital photographs. A point rating system or a descriptive method applied to evaluate the studied attributes is stated separately for each feature on successive pages. This approach creates a hierarchical assessment system. The attributes are used to calculate $E Q R$ values for every feature, and the arithmetic mean of those values constitutes the $E Q R$ of the element. The ecological quality ratios are stated in the range of $0.0-0.1$ to an accuracy of 0.01 . The same method is applied to calculate the $E Q R$ for the investigated water body as the arithmetic mean determined for all four elements (Tab. 4).

A field protocol is compiled based on all data accumulated as part of the described approach. It is updated during field surveys covering minimum $10 \%$ of the studied water body's length. Field surveys should identify the following main features: W-5 Damming structures, W-8 Cross section, W-10 Revetment of the channel, W-11 River channel vegetation, W-12 Structure of the riparian zone. The results of field surveys are used to modify the office protocol and calculate ecological quality ratios.

Based on the resulting $E Q R$ values, the investigated water body is classified into one of five ecological status classes. Pursuant to the Framework Water Directive, all rivers have to conform to class 1 and class 2 requirements. This require- 
Table 4. Excerpt from an office protocol for hydromorphological surveys of natural and heavily modified rivers

\section{E-3 ELEMENT 3 - RIVER CHANNEL MORPHOLOGY}

The following features are evaluated: river course, degree of regulation, longitudinal profile, cross-channel profile, reinforcing structures, river channel vegetation, structure of the littoral zone

\begin{tabular}{c|c|c}
\hline Attribute & Evaluation method & Points \\
\hline
\end{tabular}

Range of river regulation

\section{Feature W-6 - planform}

$<0 \%$ of water body length $\quad 5$

$10-50 \%$ of water body length 3

$>50 \%$ of water body length 1

Sinuosity index $(k)$

(lowland rivers only)

Ratio of water body length to valley

length

$k \geq 1.3$

$k 1.3-1.05$

$k \leq 1.05$

Number of channels

braided channel

single channel 3

Max. $(M)$ : ... points, Evaluation $(O) \ldots$ points $\operatorname{EQR}(\boldsymbol{O}: \boldsymbol{M}) \mathbf{W}-\mathbf{6}=\mathbf{0}, \ldots$

\section{Feature W-7- longitudinal section}

Average longitudinal slope according to a Average slope ...\% none map in the 1:10 000 scale

Variability of longitudinal slope

high $\quad 5$

average 3

low 1

Max. $(M)$ : ... points, Evaluation $(O) \ldots$ points $\operatorname{EQR}(\boldsymbol{O}: \boldsymbol{M}) \mathbf{W}-\mathbf{7}=\mathbf{0}, \ldots$

\section{Feature $\mathrm{W}-10$ - revetment of the channel}

Reinforcing structures. Channel has vertical banks built of rock, concrete or a tight steel wall; banks are reinforced with enrockment, gabions, concrete cladding, river chutes (ramps, rapids), spurs, current deflectors; channel transition into a pipeline (without share in \% length of both banks: none 5

low $<5 \%$ 4

average $5-30 \%$

high $30-50 \%$

spillways), siphon, boat and ferry harbours, very high $>50 \% \quad 1$ other*

Movement of sediment

natural, no aggregate mining 5

(dragged and floating)

visible erosion and colmatage $\quad 3$

disrupted, aggregate mining 1

Max. $(M): \ldots$ points, Evaluation $(O) \ldots$ points $\operatorname{EQR}(\boldsymbol{O}: M) \mathbf{W}-\mathbf{1 0}=\mathbf{0}, \ldots$

Ecological Quality Ratio (EQR) OF THE RIVER CHANNEL MORPHOLOGY ELEMENT

(arithmetic mean of features W6-W12)

$(0, \ldots+0, \ldots+0, \ldots+0, \ldots+0, \ldots+0, \ldots): 6=\quad \boldsymbol{E Q R}=\mathbf{0}, \ldots$

Ecological Quality Ratio (EQR) of the water body

(arithmetic mean of quality elements 1-4)

$$
(0, \ldots+0, \ldots+0, \ldots+0, \ldots): 4=\quad \boldsymbol{E Q R}=\mathbf{0}, \ldots
$$


ment is very difficult to meet. Natural watercourses have higher class 2 boundary values $(E Q R)$, than heavily modified water bodies, while the lowest values are reported in respect of artificial water bodies.

Hydromorphological survey results are compiled in a special database kept by the Institute of Meteorology and Water Management. The data are used to develop maps where ecological status and ecological potential classes are assigned five color codes, as per WFD requirements. The hydromorphological features of watercourses in river basins, water regions and other areas are described based on MHR data.

\section{DISCUSSION AND SUMMARY}

The first methods for evaluating river ecomorphology were developed in Germany in the 1980s. In 1985-2009, new methods were proposed by other countries where a water body's ecological status was assessed based on selected features. The identified features were compared against ecological status features dating back to the $19^{\text {th }}$ century with the use of a point rating system comprising $20-40$ features. European standard No. 14614 identifies 10 features. The selection of features varied significantly and in most cases, it did not account for the hydrological regime, river passability for aquatic organisms and sediment discharge. The Water Framework Directive placed EU Member States under an obligation to monitor the hydromorphological status of their rivers, and selected countries (Czech Republic, Denmark, Poland, Slovakia) have developed new methods for hydrological river surveys. The assessment of the hydrological regime proved to be most problematic. A point rating system for evaluating ecological status ratios was popularly applied in line with guidelines prEN 15843. Most methods relied on five ecological status classes, of which only class 1 and class 2 correspond to a good ecological status required by the WFD.

The new Polish MHR method draws upon the experiences of various countries. It is fully consistent with the requirements of the Water Framework Directive and standard No. 14614. The method accounts for the provisions of other EU directives listed above and Polish regulations, and it supports the performance of river surveys by 2015 . The method relies on cartographic maps, databases and geographic information systems. It has been tested in 2009 on 11 pilot water bodies in various parts of Poland. Office and field protocols enable the calculation of ecological quality ratios based on a clearly defined list of 16 features and 81 attributes. Only $25 \%$ of those attributes are presented in descriptive form, while the remaining items are evaluated on a point rating scale. The calculation of EQR for all features permits the identification of factors that prevent the attainment of a good ecological status and, therefore, require recovery measures. 


\section{CONCLUSIONS}

The Hydromorphological River Survey method MHR is fully consistent with EU and Polish regulations, and it has been developed in view of the relevant experiences acquired by other countries. The method supports the achievement of deadlines for implementing river survey programs, set for 2015 by the Water Framework Directive.

\section{REFERENCES}

1. Atlas podziału hydrograficznego Polski, 2005. Cz. 1. Mapy w skali 1:200 000. Cz. 2. Zestawienia zlewni. (Atlas of hydrographic division of Poland. Maps in the scale 1:200 000. Part 2. List of catchment basins) Pr. zbior. Red. H. Czarnecka. Warszawa, IMGW.

2. Common Implementation Strategy (CIS) for the Water Framework Directive (WFD) 2000/60/EC [online] http://circa.europa.eu/Public/irc/env/wfd/library?1=framework_directive/guidance documents\&vm $=$ detailed $\& s b=$ Title.

3. Guidance $\mathrm{nr}$ 10. River and lakes - Typology, reference conditions and classification systems. WG 2.3. REFCOND, 2003.

4. EN 14614:2004. Water quality - Guidance standard for assessing the hydromorphological features of rivers. Brussels, CEN. PN-EN 14614. Warszawa, PKN.

5. Ilnicki P., GoŁdyn R., Murat-BŁażejewska S., Soszka H., Górecki K., Grzybowski M., KRZEMiŃSKa A., LewANDOwSKi P., SKocki K., SoJKA M., 2009. Opracowanie metodyk monitoringu i klasyfikacji hydromorfologicznych elementów jakości jednolitych części wód rzecznych i jeziornych zgodnie z wymogami Ramowej Dyrektywy Wodnej. (Elaboration of methods for monitoring and classification of hydro-morphological quality parameters of uniform parts of river and lake waters acc. to the requirements of the Water Framework Directive) GEPOL Poznań dla GIOŚ Warszawa, typescript: 1-338.

6. ILNICKI P., LEWANDOWSKI P., 1995. Metodyka ekomorfologicznej waloryzacji koryt rzecznych. (The method of eco-morphological evaluation of river channels) Zeszyty Naukowe AR Wrocław Konf. 10, 1, 270: 61-67.

7. IlniCKi P., Łoś M.J., Żelazo J., 2010. Typy abiotyczne polskich rzek. (Abiotic parts of Polsih rivers). Gospodarka Wodna 4: 137-144.

8. PN-EN ISO 14688-2:2006. Badania geotechniczne. Oznaczanie i klasyfikowanie gruntów. Cz. 2. Zasady klasyfikowania. (Geo-technical investigation and testing. Identification and classification of soils. Part 2: Principles of classification) Warszawa, PKN.

9. Raport dla obszaru dorzeczy Odry i Wisły z realizacji art. 5 i 6 oraz zał. II, III, IV Ramowej Dyrektywy Wodnej, 2005. (Report from the realization of articles 5 and 6 and appendices II, III and IV of the Water Framework Directive for the Odra and Vistula rivers catchment basins) Warszawa, MŚ [online] www.kzgw.gov.pl/pl/Raporty-do-Komisji-Europejskiej.html

10. Rastrowa mapa podziału hydrograficznego Polski MPHP, 2008. (Raster map of the hydrographic division of Poland), [online] www.kzgw.gov.pl/665.html.

11. prEN 15843 Water quality - Guidance standard on determining the degree of modification of river hydromorphology (draft), 2009. Brussels.

12. Regulation (EC) No $1882 / 2003$ of the European Parliament and of the Council of 29 September 2003 adapting to Council Decision 1999/468/EC the provisions relating to committees which assist the Commission in the exercise of its implementing powers laid down in instruments subject to the procedure referred to in Article 251 of the EC Treaty. Official Journal of the European Union L 284/1. 
13. Szoszkiewicz K., LeŚny J., Staniszewski R., Mendyk D., 2004. Zróżnicowanie parametrów hydromorfologicznych w ocenie rzek niżowych metodą River Habitat Survey (RHS). (Differentiation of hydro-morphological parameters in the assessment of lowland rivers with the River Habitat Survey method) Przegląd Naukowy Wydziału Melioracji i Inżynierii Środowiska SGGW, 13 30: 67-76.

14. Technical support in relation to the implementation of the Water Framework Directive (2000/60/EC). A user guide to the WFD reporting schemas, 2009. Report Ref. V4.322.

\section{STRESZCZENIE}

\section{Podstawowe zasady monitoringu hydromorfologicznego polskich rzek}

Słowa kluczowe: metoda, ocena hydromorfologii rzek, Ramowa Dyrektywa Wodna, monitoring

W pracy przedstawiono podstawowe założenia nowej, polskiej metodyki monitoringu hydromorfologicznego rzek (MHR), dostosowanej do wymogów Ramowej Dyrektywy Wodnej. Zgodnie z nią przewiduje się badanie jedynie całego głównego cieku jednolitej części wód. Ocena opiera się na materiałach kartograficznych i teledetekcyjnych oraz istniejących bazach danych. Prace terenowe wykonuje się w ograniczonym zakresie. Do oceny stanu i potencjału ekologicznego stosowany jest system hierarchiczny. Zakłada on dokonanie oceny czterech elementów: reżimu hydrologicznego, ciągłości rzeki, morfologii koryta i doliny zalewowej. Są one oceniane na podstawie licznych wskaźników charakteryzowanych przez wybrane atrybuty. W analogiczny sposób bada się cieki naturalne i silnie zmienione, w uproszczony cieki sztuczne. Sposób ten nie różni się dla wydzielonych typów biotycznych, krajobrazów i wielkości zlewni cieku. Wyniki oceny są prezentowane w protokołach kameralnych i terenowych. Atrybuty podlegają ocenie punktowej lub opisowej, która umożliwia obliczenie współczynników jakości ekologicznej wskaźników, elementów oraz jednolitej części wód. Przydatność metody MHR została sprawdzona w 11 pilotowych jednolitych częściach wód. Stwarza ona możliwość przeprowadzenia wymaganej oceny hydromorfologii cieków w Polsce do końca 2015 r., czego wymaga Ramowa Dyrektywa Wodna.

Received 07.07.2010

Reviewers:

Prof. Sadzide Murat-Btażejewska

Prof. Jan Żelazo 